IOS Press

\title{
Should the dose of folic acid be adjusted for Mexican population? The pilot prevention program implemented in Nuevo Leon, Mexico
}

\author{
Laura E. Martinez de Villarreal \\ Universidad Autónoma de Nuevo León, Hospital Universitario “Dr. José Eleuterio González”, Departamento de \\ Genética, Av. Gonzalitos s/n, Colonia Mitras Centro, Monterrey, Nuevo León 64460, México \\ Tel.: +52 81 83294217; E-mail: laelmar@yahoo.com.mx
}

Accepted 26 September 2017

\begin{abstract}
In 1980 Smithells et al. reported that the intake of folic acid (FA) prevents the recurrence of neural tube defects (NTDs) [1]. After this and several other studies were conducted, the intake of 400 micrograms of folic acid per day, at least three months before and three months during pregnancy for prevention of NTD, was proposed [2,3,4]. Other strategies were also developed to increase folate blood levels in woman of childbearing age such as promoting the consumption of folate rich foods and food fortification (flour and most recently rice) [5]. Nevertheless, results have not been as expected due to poor consumption of folic acid supplements [6]. As a result, in the year 2000, a novel strategy was developed in order to increase folate blood levels in Mexican women. The results of the strategy are presented, as well as, a discussion about how to personalize a program for different populations.
\end{abstract}

Keywords: Folic acid, NTD, spina bifida, prevention, mexican population

\section{Introduction}

In Nuevo Leon, a state located at Northeast Mexico, close to the border with Texas, USA, there are 90,000 births/year. Since 1999, birth defects are the second leading cause of infant mortality and NTDs are the second leading cause of death for those born with a birth defect. The NTD incidence rate in 1999 was $10.6 / 10,000$ [7]. As a result of the serious nature of NTDs, and with the knowledge that many could be prevented with adequate prenatal and early pregnancy folic acid supplementation, we started a NTD prevention campaign in the year 2000. While the recommended 400 micrograms FA dose was not available in Mexico, a $5.0 \mathrm{mg}$ tablet was accessible. In addition, patient willingness to take the medication was a serious barrier.
As a result, a research protocol was established to analyze the impact of the intake of $5.0 \mathrm{mg}$ of FA per week. Participants in the study were mothers with and without a history of a NTD pregnancy. Results showed that after 3 months there was a compliance rate of 91.4\% and a significant increase in plasma and red blood cell folate (RBC). It is important to mention that the basal blood levels were low and post implementation, increased to $200 \mathrm{ng} / \mathrm{dl}(432 \mathrm{nMol} / \mathrm{L})$ [8]. With these results, a NTD prevention program was initiated by the State Secretary of Health, together with the School of Medicine of the University of Nuevo Leon. The program included the following components: 1) a registry of NTDs in private and public hospitals, 2) information and education for both health professionals and the target population, 3) free distribution of $5 \mathrm{mg}$ tablets of FA to all women at reproductive age (ap- 
proximately 750,000 women), 4) promotion and supervision of intake, and 5) an evaluation of the results. There was a significant reduction $(50 \%)$ in the number of cases of both anencephaly and spina bifida [9].

Controversy remains over the optimal dose of FA for NTD prevention. Studies done by Daly established that the RBC threshold for prevention is $400 \mathrm{ng} / \mathrm{dl}$ or $906 \mathrm{nMol} / \mathrm{L}$, and more recently Crider, using different doses of FA, established that there could be a higher reduction of cases by increasing the threshold. It is important to note that Wald (2001) reported that there is a dose response relationship and also established that FA content in most of the multivitamins were sufficient to increase folate blood levels up to $400 \mathrm{ng} / \mathrm{dl}$ [10].

Recently there have been reports that there are individual differences that modify the pharmacokinetics and pharmacodynamics of FA. Some of these differences include 1) concentration and time needed to achieve a steady-state concentration of folic acid in a woman planning pregnancy (varying from 6 months to one year), 2) poor compliance, 3) lack of pregnancy planning (50\% of pregnancies are unintended), 4) differences in folic acid metabolism with a study demonstrating that administration of $5 \mathrm{mg} /$ day increases by 5 the AUC in serum, but only 2 times in RBC as compared to $1 \mathrm{mg} /$ day, indicating that, the body may take "as much as it needs" and limits excessive absorption, 5) a diet inadequate in folic acid, 6) degradation of natural folates, 7) use of some drugs such as oral contraceptives, that interfere with absorption, and 8) genetics. There are several studies indicating that polymorphisms exist in genes like MTHFR (Methylenetetrahydrofolate reductase) $(677 \mathrm{C}>\mathrm{T})$, FAR (folic acid receptor), MTHD (Methylenetetrahydrofolate deshydrogenase), and TS (Thymidylate synthase) [10]. In a previous study, we found that $40 \%$ of women that had a child with a NTD were homozygous for the MTHFR C $>$ T677 polymorphism compared to only $9 \%$ of mothers with a child without a NTD. In addition, $75 \%$ of mothers with affected babies were folate deficient [11]. Studies have shown that this polymorphism is very common in other Mexican populations [12].

Other important NTD risk factors are present among the Mexican population including: 1) the antecedent of NTD (previous child or close family member), 2) obesity ( $45 \%$ of women in Nuevo León with a baby with a NTD were overweight/obese [13], 3) genetic variants in the folic acid metabolic pathway or folate receptors, 4) poorly controlled type 1 or type 2 diabetes mellitus (diabetes is a serious health problem in Mexico), and 5) poor compliance with folic acid supplementa- tion. Recently, the World Health Organization (WHO) and the US Centers for Disease Control and Prevention (CDC) published guidelines indicating that the population threshold level for RBC folate concentrations should be $>400 \mathrm{ng} / \mathrm{mL}(906 \mathrm{nmol} / \mathrm{L})$ to achieve the greatest reduction of NTDs, and this can be used as an indicator of folate insufficiency in women of reproductive age. The guidelines also included rules for implementation, such as the assessment of the RBC folate status among women of reproductive age, and depending on population status, determining the need for interventions, such as fortification of staple foods with folic acid or periconceptional folic acid supplementation. Also included were guidelines as to how best reach populations at risk for insufficient folate concentrations, reassess population RBC folate status (at least 6-12 months after the intervention), make adjustments to the prevention program as necessary, and maintain a registry of cases to monitor program success [13]. In the previous study, before fortification, our population had half of this level.

Although several strategies have been implemented in Mexico, including fortification of corn and wheat flour and promotion and distribution of folic acid, it appears only a slight reduction of cases has been observed [15]. It should be considered also that the NTD registry might not be completely reliable yet. In addition, there are risks associated with higher doses of folic acid, including neurocognitive conditions, like autism; however, this has been seen only with a dose higher than $5 \mathrm{mg} /$ day. There may also be a higher risk for certain cancers, but there is not sufficiently conclusive evidence for this, as more studies are needed to evaluate this risk.

A number of questions remain. Should Mexicans take 4-5 mg/day of FA for NTD prevention? Is it possible to reduce incidence of NTD in Mexico by increasing the dose of FA? Should further studies be done to ascertain RBC folate levels? Should additional folic acid be recommended by non-folate risk factors in the population? These questions must be answer in order to have a tailored made program for our country, which may be applicable to other Latin American countries as well.

\section{Conflict of interest}

None to report. 


\section{References}

[1] Smithells RW, Shephard S, Schorah CJ, et al. Possible prevention of neural-tube defects by periconceptional vitamin supplementation. Lancet 1980; I: 339-40.

[2] Smithells RW, Sheppard S, Schorah C, et al. Apparent prevention of neural tube defects by periconceptional vitamin supplementation. Arch Dis Child 1981; 56: 911-18. Reprinted Int J Epidemiol 2011; 40: 1146-54.

[3] MRC Vitamin Study Research GroupPrevention of neural tube defects: results of the Medical Research Council Vitamin Study, Lancet 1991; 338: 131-37.

[4] Czeizel AE, Dudas I. Prevention of the first occurrence of neural-tube defects by periconceptual vitamin supplementation. N Engl J Med 1992; 327: 1832-35.

[5] Centers for Disease Control and Prevention. Recommendations for the use of folic acid to reduce the number of cases of spina bifida and other neural tube defects. Morb Mortal Wkly Rep 1992; 41: 1-8.

[6] Botto LD, Lisi A, Robert-Gnansia E, et al. International retrospective cohort study of neural tube defects in relation to folic acid recommendations: are the recommendations working? BMJ: British Medical Journal 2005; 330(7491): 571. doi: $10.1136 / \mathrm{bmj} .38336 .664352 .82$.

[7] Martínez de Villarreal LE, Ayala Alvarado C, Limón Benavides C. Defectos congénitos y mortalidad infantil en el estado de Nuevo León. Med Universitaria 1999; 1(3): 113-7.

[8] Martinez de Villarreal LE, Limon Benavides C, Valdez leal R, Sanchez Peña MA and Villarreal Perez JZ. Efecto de la administración semanal de acido folio sobre los valores sanguíneos. Salud Publica de Mexico 2001; 43(2): 103-107.

[9] Martínez de Villarreal L, Pérez JZ, Vázquez PA, Herrera RH, Campos Mdel R, López RA, Ramírez JL, Sánchez JM, Villarreal JJ, Garza MT, Limón A, López AG, Bárcenas M, García JR, Domínguez AS, Nuñez RH, Ayala JL, Martínez JG, González MT, Alvarez CG, Castro RN. Decline of neural tube defects cases after a folic acid campaign in Nuevo Leon Mexico Teratology 2002 Nov; 66(5): 249-56.
[10] Chitayat D, Matsui D, Amitai Y, Kennedy D, Vohra S, Rieder M, Koren G. Folic acid supplementation for pregnant women and those planning pregnancy: 2015 update. The Journal of Clinical Pharmacology 2016; 56(2): 170-175.

[11] Martínez LE, Delgado I, Valdez R, Ortiz R, Rojas A, Limón C, et al. Folate levels and N5, N10-methylenetetrahidrofolate reductase genotype (MTHFR) in mothers of offspring with neural tube defects: a case-control study. Arch Med Res 2001; 32: $277-282$.

[12] Contreras-Cubas C, Sánchez-Hernández BE, García-Ortiz H, Martínez-Hernández A, Barajas-Olmos F, Cid M, MendozaCaamal EC, Centeno-Cruz F, Ortiz-Cruz G, Jiménez-López JC, Córdova EJ, Salas-Bautista EG, Saldaña-Alvarez Y, Fernández-López JC, Mutchinick OM, Orozco L. Heterogenous Distribution of MTHFR Gene Variants among Mestizos and Diverse Amerindian Groups from Mexico. PLoS One 2016 Sep 20; 11(9): e0163248.

[13] Fernandez Gancedo A, Hinojosa Amaya AB, Ibarra Ramirez M, Martinez de Villarreal 1. BMI and Pregnancy Weight Gain as Risk Factors for NTD: A case study in a Northeast Mexican Third Level Hospital. Clin and Mol Teratology (Abstract 56 Annual Meeting, San Antonio Tx) 2015; 106(5): 422.

[14] Cordero AM, Crider KS, Rogers LM, Cannon MJ, Berry RJ. Morbidity and Mortality Weekly Report 2015; 64(15): 421423.

[15] Prevenir para la salud: Defectos del Tubo Neural y Acido Fólico en Mexico. 2011. 14 Congreso de salud Publica de Mexico. Cuernavaca Morelos. Instituto Nacional de Salud Pública de México. https:/www.insp.mx/noticias/1596defectos del tubo neural y acido folico en mexico.html. 